\title{
Theoretical study of cobalt and nickel complexes involved in methyl transfer reactions: structures, redox potentials and methyl binding energies
}

\author{
Patrycja Sitek $^{1} \cdot$ Aleksandra Chmielowska $^{1} \cdot$ Maria Jaworska $^{1}$ (D) . Piotr Lodowski ${ }^{1} \cdot$ Marzena Szczepańska $^{1}$
}

Received: 25 March 2019 / Accepted: 25 June 2019 / Published online: 29 July 2019

(C) The Author(s) 2019

\begin{abstract}
Cobalamins, cobalt glyoximate complexes and nickel complexes with Triphos (bis(diphenylphosphinoethyl)phenylphosphine) and $\mathrm{PPh}_{2} \mathrm{CH}_{2} \mathrm{CH}_{2} \mathrm{SEt}$ ligands were studied with the DFT/BP86 method in connection with methyl transfer reactions. Geometries, methyl binding energies and redox potentials were determined for the studied complexes. Three- and fourcoordinate structures were considered for nickel complex with $\mathrm{PPh}_{2} \mathrm{CH}_{2} \mathrm{CH}_{2} \mathrm{SEt}$ ligand, whereas four- and five-coordinate for its methyl derivative. On the basis of calculations, the possible mechanism of methyl transfer reaction between cobalt and nickel complexes was considered.
\end{abstract}

Keywords Nickel complexes $\cdot$ Cobalt complexes $\cdot$ DFT $\cdot$ Redox potentials $\cdot$ Methyl transfer

\section{Introduction}

The $\mathrm{B}_{12}$ vitamin derivatives (cobalamins) present in methyltransferases take part in many enzymatic methyl transfer reactions [1-3]. A unique methyl transfer reaction, where metals act as donors and acceptors of the methyl group, is found in the acetyl-CoA (Ljungdahl-Wood) pathway of autotrophic carbon fixation in various bacteria and archaea [4]. Acetyl-CoA is synthesized at the Ni-Ni[4Fe-4S] cluster (the A-cluster) of acetyl-CoA synthase (ACS) through condensation of coenzyme-A (CoASH) with $\mathrm{CO}$ and the methyl group from $\mathrm{CH}_{3}-\mathrm{Cob}(\mathrm{III})$ alamin of the corrinoid-iron-sulfur protein (CoFeSP) [5, 6]. A key step of such synthesis is the transfer of the methyl group from CoFeSP to the proximal $\mathrm{Ni}$ atom in the active site of ACS [7]. This reaction proceeds according to the equation:

$$
\begin{aligned}
\mathrm{CH}_{3} & -\mathrm{Co}(\mathrm{III}) \mathrm{FeSP}+\mathrm{CO}+\mathrm{CoASH} \mathrm{H}^{-} \mathrm{SCoA}+\mathrm{Co}(\mathrm{I}) \mathrm{FeSP}+\mathrm{H}_{3}^{+}
\end{aligned}
$$

Electronic supplementary material The online version of this article (https://doi.org/10.1007/s11224-019-01384-z) contains supplementary material, which is available to authorized users.

Maria Jaworska

mj@ich.us.edu.pl

1 Institute of Chemistry, University of Silesia in Katowice, Szkolna 9, 40-006 Katowice, Poland
The occurrence of $\mathrm{Ni}(0)[8,9]$ or $\mathrm{Ni}(\mathrm{I})$ [10] in reaction (1) of ACS was postulated. Since the mechanism of catalytic action of the ACS enzyme is not fully understood [8, 11-13], models of methylation reactions involving nickel complexes and various methylation factors are being examined experimentally [9, 14-19]. Likewise, many complexes relevant to ACS enzyme are investigated experimentally [20-24] and computationally [25-29]. Examples of methylation reactions with nickel participation are [10, 28]:

$$
\begin{aligned}
& \mathrm{Ni}(\text { Triphos }) \mathrm{PPh}_{3}+\mathrm{CH}_{3}-\mathrm{Co}\left(\mathrm{dmgBF_{2 } ) _ { 2 } p y + s o l} \longrightarrow\right. \\
& \mathrm{Ni}(\text { Triphos }) \mathrm{CH}_{3}^{+}+\mathrm{Co}\left(\mathrm{dmgBF_{2 }}\right)_{2} \mathrm{sol}^{-}+\mathrm{PPh}_{3}+p y,
\end{aligned}
$$

where Triphos stands for bis(diphenylphosphinoethyl)phenylphosphine ligand, and

$$
\begin{aligned}
& \mathrm{Ni}\left(\mathrm{PPh}_{2} \mathrm{CH}_{2} \mathrm{CH}_{2} \mathrm{SEt}\right)_{2}+\mathrm{CH}_{3} \mathrm{~J} \longrightarrow \\
& \mathrm{Ni}\left(\mathrm{PPh}_{2} \mathrm{CH}_{2} \mathrm{CH}_{2} \mathrm{SEt}\right)_{2} \mathrm{CH}_{3}^{+}+\mathrm{J}^{-} .
\end{aligned}
$$

In general, two mechanisms $-\mathrm{S}_{N} 2$ and radical-are possible in methyl transfer reactions with cobalamin participation [28, 30, 31]. Both reactions (2) and (3) involve methylation of nickel( 0$)$ complexes. In the first step of the radical reaction, the methyl derivative should be reduced by the methyl acceptor; thus, the homolytic cleavage of Co$\mathrm{CH}_{3}$ bond is initiated by electron transfer between reactants. The radical mechanism is therefore possible when methyl acceptor is able to reduce methyl donor. 
For theoretical modelling of such reactions with the use of DFT method, it is extremely important to apply a functional which properly describes electronic structure of the reactants, giving the results comparable with experiment. This is especially important for methyl-metal binding energy and oxidation-reduction properties of the reacting complexes. In this work, the calculational study was carried out for nickel and cobalt complexes pertinent to biological (1) and model (2), (3) methyl transfer reactions with the use of DFT method and nonhybrid functional BP86. This functional allows to get a good description of the cobalt-methyl bond in alkylcobalamins, while the hybrid functionals significantly underestimate the energy of this bond [32-35]. Calculations for transition metal complexes show that BP86 functional gives also good estimation for redox potentials [36-38]. In the present study, BP86 is used to determine geometry, methyl binding energies and redox potentials for the investigated cobalt and nickel complexes. The results are compared with the experimental data.

\section{Method of calculations}

The calculations were carried out with the use of Gaussian16 program [39]. The DFT method with BP86 [40, 41] functional and TZVP [42] basis sets were used in the calculations. The effect of environment was taken into account by PCM solvent model [43-45], with water (for Co complexes) and acetonitrile (for Ni complexes) as solvents. The geometry of all studied complexes was fully optimized. The zero point energy (ZPE) and G3 dispersion correction $[46,47]$ were added to the calculated binding energies.

Methylcobalamin (MeCbl) is a methyl derivative of vitamin $\mathrm{B}_{12}$ which is uses in methyltransferases enzymes as a methylation factor. In CoFeSP protein it exists as a base-off form. The base-on form of methylcobalamin has dimethylbenzimidazole (DMB) as a ligand trans to methyl [2]. In the base-off form, DMB is replaced by a water ligand. The base-on and base-off forms are shown in Fig. S1 (Supporting Material).

In the present study, the base-on and base-off structures were examined in the form of simplified models, in which all the corrin (denoted further as Cor) side chains were replaced by hydrogen atoms and for base-on methylcobalamin the 5,6-dimethylbenzimidazole trans axial base was replaced by imidazole [48]. The base-off form without trans axial base and with water molecule as ligand was also considered. The calculations for cobalt complexes without methyl ligand were also performed for the sake of comparison with the experimental data.

The calculations for cobalt dimethylglyoxime complexes and nickel complexes were carried out, in reference to the reactions (2) and (3). The $\mathrm{Ni}\left(\mathrm{PPh}_{2} \mathrm{CH}_{2} \mathrm{CH}_{2} \mathrm{SEt}\right)_{2}$ complex was examined with nickel in three oxidation states: $\mathrm{Ni}(\mathrm{II})$, $\mathrm{Ni}(\mathrm{I})$ and $\mathrm{Ni}(0)$ which were studied experimentally [10]. In the case of the one and two-electron reduced complex the four and three coordinated complexes were investigated. For $\mathrm{Ni}$ (Triphos) $\mathrm{PPh}_{3}$ complex, the calculations were performed in the neutral and oxidized state. The relevant methyl derivatives of nickel complexes were also studied.

\section{Results and discussion}

The aim of this work is to compare the properties of nickel and cobalt methyl derivatives in relation to methyl transfer reactions. It is essential in context of reactions (1) and (2), where the methyl group is transferred between the two metal centers, from cobalt to nickel. The important question is what properties of these complexes cause the reaction to run in this direction, what is the relative strength of methyl binding and other electron properties. It could help to explain the occurrence of nickel in the ACS enzyme and the unique biological properties of ACS enzyme. To the best of our knowledge, there are no studies with theoretical methods for methyl nickel complexes in the literature. The cobalamin-methyl complexes were extensively investigated theoretically [3, 32, 33, 35, 49-61] due to their enormous significance in biological processes. We performed also the calculations for cobalt complexes to have consistent data set obtained with the same method, basis set, solvent and other computational conditions.

\section{Structure}

The axial ligand distances for cobalt complexes and methylnickel bond lengths for nickel complexes are collected in Table 1. The obtained structures are presented in Figs. 1, 2, 3, 4, and 5. In Supporting Information, the total energies and selected geometrical parameters of the investigated complexes are given in Table S1 and Tables S2, S3, S4, and S5, respectively.

\section{Cobalt complexes}

For cobalamin and dimethylglyoxime complexes the geometry of optimized structures are shown in Figs. 1 and 2, respectively. The axial ligand bond lengths are gathered in Table 1. Other selected geometrical parameters for cobalamins and cobaloximes are presented in Tables S1 and S2, respectively and the numbering of atoms in Fig. S2.

For cobalamins, the most notable features are related to geometry changes occurring upon reduction. After reduction of the five-coordinated complex CoCorIm, the imidazole ligand dissociates and the four-coordinated CoCor(I) complex is formed. This is in agreement with the experimental 
Table 1 Selected distances $(\AA)$ in Co and Ni complexes

\begin{tabular}{|c|c|c|c|c|}
\hline & & & Calc. & Exp. \\
\hline \multirow[t]{2}{*}{$\mathrm{CH}_{3} \mathrm{CoCorIm}^{+}$} & & $\mathrm{Co}-\mathrm{C}_{\mathrm{CH}_{3}}$ & 1.990 & $1.972^{\mathrm{a}}$ \\
\hline & & $\mathrm{Co}-\mathrm{N}_{I m}$ & 2.178 & $2.093^{\mathrm{a}}$ \\
\hline \multirow[t]{2}{*}{$\mathrm{CH}_{3} \mathrm{CoCorIm}$} & & $\mathrm{Co}-\mathrm{C}_{\mathrm{CH}_{3}}$ & 1.981 & \\
\hline & & Co-N $\mathrm{N}_{I m}$ & 2.169 & \\
\hline $\mathrm{CH}_{3} \mathrm{CoCor}^{+}$ & & $\mathrm{Co}-\mathrm{C}_{\mathrm{CH}_{3}}$ & 1.971 & \\
\hline $\mathrm{CH}_{3} \mathrm{CoCor}$ & & $\mathrm{Co}-\mathrm{C}_{\mathrm{CH}_{3}}$ & 1.959 & \\
\hline CoCorIm $^{+}$ & & $\mathrm{Co}-\mathrm{N}_{I m}$ & 2.160 & \\
\hline CoCorIm & & $\mathrm{Co}-\mathrm{N}_{I m}$ & 19.745 & \\
\hline \multirow[t]{2}{*}{$\mathrm{CH}_{3} \mathrm{CoCorH}_{2} \mathrm{O}^{+}$} & & $\mathrm{Co}-\mathrm{C}_{\mathrm{CH}_{3}}$ & 1.974 & \\
\hline & & $\mathrm{Co}-\mathrm{O}_{\mathrm{H}_{2} \mathrm{O}}$ & 2.370 & \\
\hline \multirow[t]{4}{*}{$\mathrm{CH}_{3} \mathrm{CoCorH}_{2} \mathrm{O}^{\mathrm{d}}$} & & $\mathrm{Co}-\mathrm{C}_{\mathrm{CH}_{3}}$ & 1.960 & \\
\hline & & $\mathrm{Co}-\mathrm{H} 2 \mathrm{H}_{2} \mathrm{O}$ & 3.073 & \\
\hline & & $\mathrm{N} 1-\mathrm{H} 1_{\mathrm{H}_{2} \mathrm{O}}$ & 2.588 & \\
\hline & & $\mathrm{N} 2-\mathrm{H} 2 \mathrm{H}_{2} \mathrm{O}$ & 2.654 & \\
\hline $\mathrm{CoCorH}_{2} \mathrm{O}^{+}$ & & $\mathrm{Co}-\mathrm{O}_{\mathrm{H}_{2} \mathrm{O}}$ & 2.304 & \\
\hline $\mathrm{CoCorH}_{2} \mathrm{O}$ & & $\mathrm{Co}-\mathrm{H}_{\mathrm{H}_{2} \mathrm{O}}$ & 2.218 & \\
\hline \multirow[t]{2}{*}{$\mathrm{CH}_{3} \mathrm{Co}\left(\mathrm{dmgBF}_{2}\right)_{2}$ py } & & $\mathrm{Co}-\mathrm{C}_{\mathrm{CH}_{3}}$ & 2.033 & $2.007^{b}$ \\
\hline & & Co- $\mathrm{N}_{p y}$ & 2.082 & $2.119^{\mathrm{b}}$ \\
\hline \multirow[t]{2}{*}{$\mathrm{CH}_{3} \mathrm{Co}\left(\mathrm{dmgBF}_{2}\right)_{2} \mathrm{py}^{-}$} & & $\mathrm{Co}-\mathrm{C}_{\mathrm{CH}_{3}}$ & 2.003 & \\
\hline & & Co- $\mathrm{N}_{p y}$ & 2.269 & \\
\hline $\mathrm{CH}_{3} \mathrm{Co}\left(\mathrm{dmgBF}_{2}\right)_{2}$ & & $\mathrm{Co}-\mathrm{C}_{\mathrm{CH}_{3}}$ & 1.980 & \\
\hline $\mathrm{CH}_{3} \mathrm{Co}\left(\mathrm{dmgBF}_{2}\right)_{2}^{-}$ & & $\mathrm{Co}-\mathrm{C}_{\mathrm{CH}_{3}}$ & 2.001 & \\
\hline $\mathrm{Co}\left(\mathrm{dmgBF}_{2}\right)_{2} \mathrm{py}$ & & Co- $\mathrm{N}_{p y}$ & 2.050 & \\
\hline $\mathrm{Co}\left(\mathrm{dmgBF}_{2}\right)_{2} \mathrm{py}^{-}$ & & Co- $\mathrm{N}_{p y}$ & 1.993 & \\
\hline $\mathrm{CH}_{3} \mathrm{Ni}\left(\mathrm{PPh}_{2} \mathrm{CH}_{2} \mathrm{CH}_{2} \mathrm{SEt}\right)_{2}^{+}$ & $\mathrm{MeVI}^{\mathrm{e}}$ & $\mathrm{Ni}-\mathrm{C}_{\mathrm{CH}_{3}}$ & 1.981 & \\
\hline $\mathrm{CH}_{3} \mathrm{Ni}$ (Triphos) $)^{+}$ & & $\mathrm{Ni}-\mathrm{C}_{\mathrm{CH}_{3}}$ & 1.975 & $1.963^{\mathrm{c}}$ \\
\hline
\end{tabular}

${ }^{\mathrm{a}}$ Ref. [82]

${ }^{b}$ Ref. [19]

${ }^{\mathrm{c}}$ Ref. [28]

${ }^{\mathrm{d}}$ Numbering of atoms is presented in Fig. S1

${ }^{\mathrm{e}}$ For the lowest energy conformer (Fig. 4 and Table S1)

data and theoretical calculation results $[3,48,51,62-64]$. In the reduced base-off methylcobalamin with a water molecule as an axial ligand the water is coordinated to cobalt by the oxygen atom. The reduction of $\mathrm{CH}_{3} \mathrm{Co}$ (III) $\mathrm{CorH}_{2} \mathrm{O}$ leads to a system with water linked by hydrogen bond to corrin nitrogens $\left(\mathrm{CH}_{3} \mathrm{Co}(\mathrm{II}) \mathrm{CorH}_{2} \mathrm{O}\right)$. In contrast to that, in the reduced methyl-free cobalt complex $\mathrm{CoCorH}_{2} \mathrm{O}$, the water molecule is bound by hydrogen bond to the cobalt atom (see Fig. 1 and Table 1). The existence of cobalt-water hydrogen bonding was predicted theoretically [64].

In the dimethylglyoxime complexes, the axial base coordinated to cobalt is pyridine (Fig. 2). The BP86 results reveal that upon reduction pyridine is not detached both in methylated and methyl-free complexes.

\section{Nickel complexes}

The structures of nickel complexes are depicted in Figs. 3, 4, 5, whereas methyl-nickel bond lengths and other selected optimized geometrical parameters are collected in Tables 1, S4, and S5.

For $\mathrm{Ni}\left(\mathrm{PPh}_{2} \mathrm{CH}_{2} \mathrm{CH}_{2} \mathrm{SEt}\right)_{2}^{2+}$ a planar structure was obtained (Fig. 3, structure $\mathbf{I}^{2+}$ ) which is in agreement with the crystal structure $[10,15]$. The one- and two-electron reduced complexes $\mathbf{I}^{+}$and $\mathbf{I}$ are characterized by a distorted tetrahedral coordination (Fig. 3 and Table S3). For the two-electron reduced molecule $\mathrm{Ni}\left(\mathrm{PPh}_{2} \mathrm{CH}_{2} \mathrm{CH}_{2} \mathrm{SEt}\right)_{2}$ which is a $\mathrm{Ni}(0)$ complex, the possibility of ligand dissociation was suggested [15]; hence, the calculations for three-coordinated 


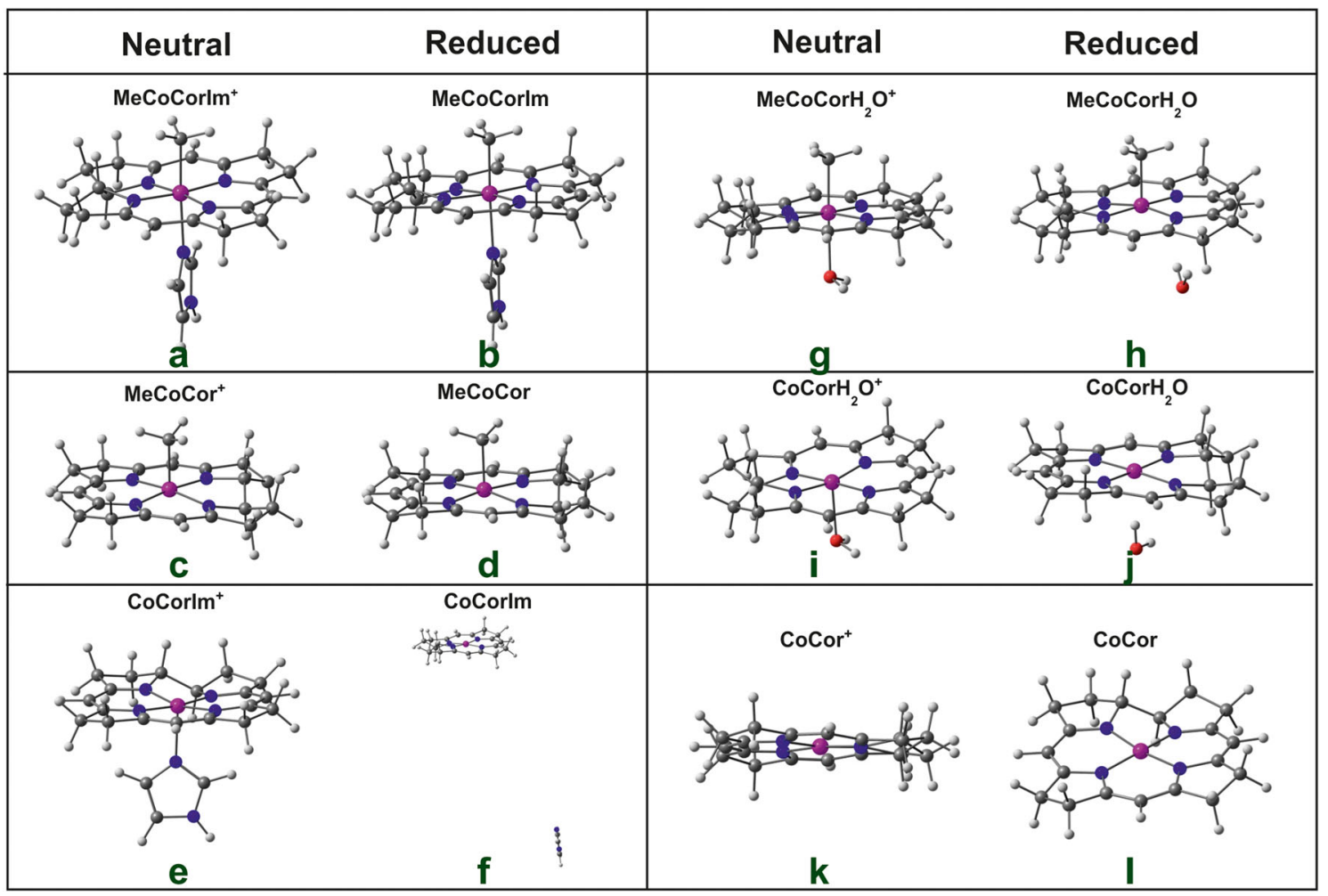

Fig. 1 The optimized structures of cobalamin complexes: ab, cd, kl reduction does not change the geometry of the complexes; ef - after reduction the imidazole ligand is detached; $\mathbf{g h}$ - after reduction the

forms of the one- and two-electron reduced complexes were also performed $\left(\mathbf{I I}^{+}-\mathbf{I I I}{ }^{+}\right.$and $\left.\mathbf{I I}-\mathbf{I I I}\right)$. II and III differ in the nickel coordination mode, in II nickel is coordinated by two phosphorus and one sulfur atom while in III by two sulfur and one phosphorus atom (Fig. 3 and Fig. S3). Optimized geometry reveals that the coordination of the nickel atom in two-electron reduced three-coordinate structures approximately corresponds to vertices of an almost equilateral triangle, while in the case of One-electron reduced twocoordinate phosphorus or sulfur atoms are almost linear (Fig. 3 and Table S3).

The computed energies (Fig. 3) show that the lowest energy complex is a four-coordinate one for both reduced states, $\mathbf{I}^{+}$and $\mathbf{I}$. The three-coordinated complex with two phosphines (II) is $6.9 \mathrm{kcal} / \mathrm{mol}$ higher in energy $(14.3 \mathrm{kcal}$ with dispersion correction) than four-coordinate I. The three-coordinate complexes in which the nickel atom is coordinated by two sulfur atoms and one phosphorus are much higher in energy.

The methylated complex $\mathrm{CH}_{3} \mathrm{Ni}\left(\mathrm{PPh}_{2} \mathrm{CH}_{2} \mathrm{CH}_{2} \mathrm{SEt}\right)_{2}^{+}$ was examined in the form of five- and four-coordination structures. The obtained structures MeI-MeVI are shown in Fig. 4. These structures differ in mutual position of sulfur and phosphorus atoms and metal coordination number where MeI and MeII are five-coordinate and MeIIMeVI are four-coordinate. The lowest energy structure is water ligand is bonded by hydrogen bond with nitrogen atoms of the corrin ring; $\mathbf{i j}$ - after reduction the water ligand is bonded by hydrogen bond with the cobalt atom

MeVI, where nickel is coordinated by two phosphorus and one sulfur atoms and where sulfur is in trans position to the methyl group. BP86 functional gives five-coordinated structure, MeII, as a second one in energy $(6.2 \mathrm{kcal} / \mathrm{mol}$, and $1.6 \mathrm{kcal} / \mathrm{mol}$ higher with dispersion correction). Basing on the NMR spectra, the fivecoordinated geometry is suggested [10]. Taking into account a small energy difference calculated with D3 correction, it is possible that sulfur ligands undergo very fast exchange process.

The nickel complexes with Triphos ligand are depicted in Fig. 5 and the optimized geometry parameters are gathered in Table S5. The Ni(Triphos) $\mathrm{PPh}_{3}$ which is a Ni(0) complex has a distorted tetrahedral structure, which is in agreement with the crystal structure [28]. Similarly the distorted tetrahedral geometry was obtained for $\mathrm{Ni}$ (Triphos) $\mathrm{PPh}_{3}^{+}$. The methyl derivative, $\mathrm{CH}_{3} \mathrm{Ni}$ (Triphos) $)^{+}$which is a $\mathrm{Ni}(\mathrm{II})$ complex, has a planar structure, which is also in accordance with the experiment [28].

\section{Methyl-metal bonding}

The methyl binding energy in the investigated cobalt and nickel complexes was computed according to the formula:

$E_{B}=\Delta E+Z P E+D 3+B S S E$, 


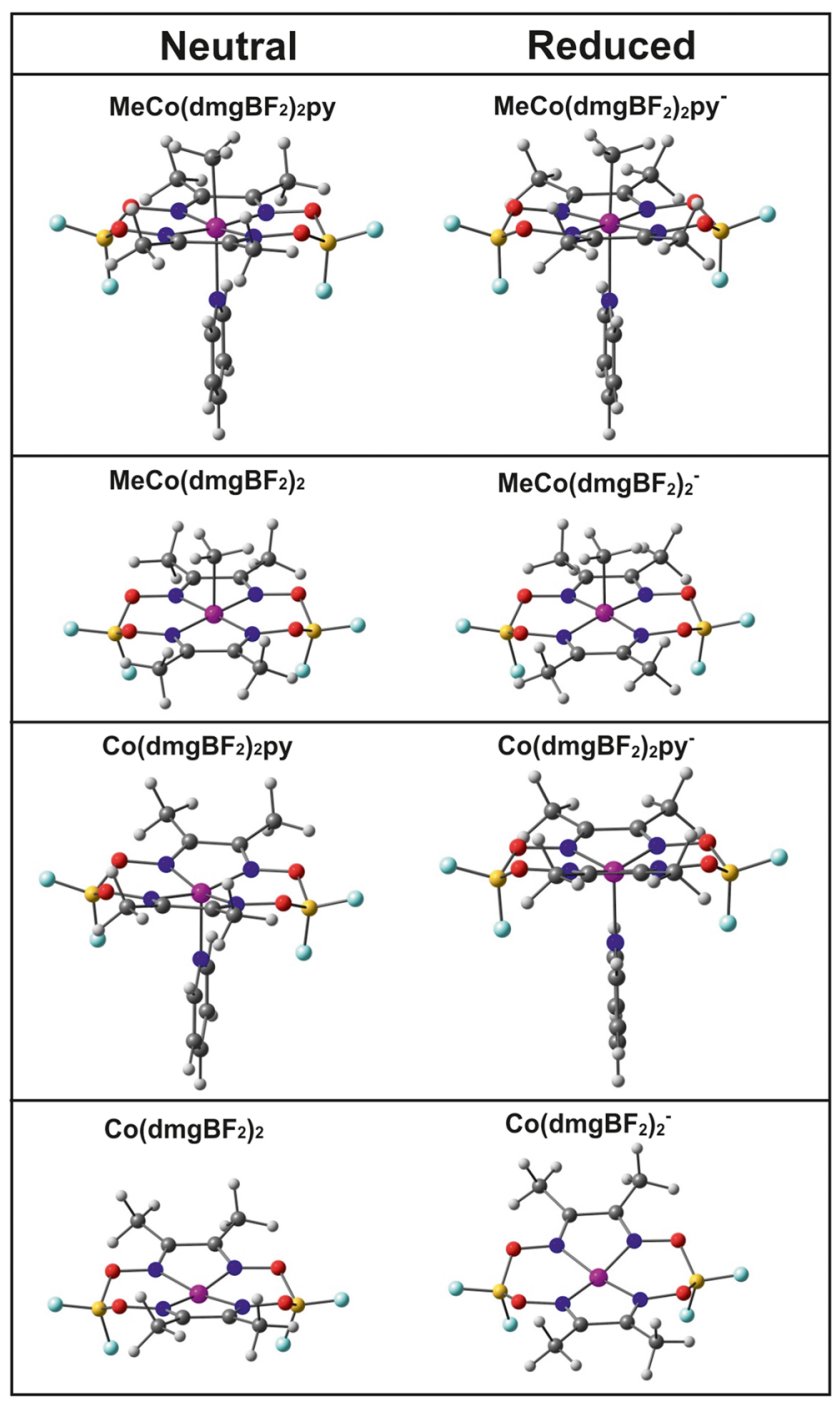

Fig. 2 The optimized structures of dimethylglyoxime cobalt complexes

where

$\Delta E=E\left(C_{3}\right)+E(M L)-E\left(C H_{3}-M L\right)$,

and ML, ZPE, D3 and BSSE denote metal complex, zero point energy, dispersion correction and basis set superposition error correction, respectively.

The obtained results are collected in Table 2 with the experimental data for comparison, where available.

There were many theoretical studies in which Co-C binding energy was calculated [3, 32-35, 49-61, 64-74]. It was shown that gradient functional BP86 gives binding energy close to experimental, while the hybrid functionals significantly underestimate its value. The TPSS functional was found to perform well in binding energy calculations for adenosylcobalamin system [73, 74]. We use BP86 as it gives good results for $\mathrm{E}_{B}$ and reduction potentials as well, as shown further. As mentioned earlier our binding energy calculations for cobalamins are performed to have consistent data set of computational results allowing for systematic comparison between cobalt and nickel complexes. Inspection of data in Table 2 reveals that the binding energies without dispersion correction are generally underestimated. The good agreement of the BP86+D3 calculated binding energies for methylcobalamin and its reduced form with experimental data $[59,75]$ is also found in the present calculations. The BSSE error is rather small (about $1.5 \mathrm{kcal}$ ) and of similar value for all complexes studied.

From the data in Table 2, it can be noted that for the reduced cobalamins ( 3 and $\mathbf{5}$, Table 2), the methyl binding energy is smaller than in the case of oxidized ones. The mechanism of methyl dissociation in the reduced methylcobalamin was studied theoretically, and it was shown that the reduction occurs on the corrin ring [76]. When looking at the spin density values collected in Table 3, one can find that indeed the unpaired electron is localized on the corrin ring in the reduced methylcobalamin. Similar pattern emerges from the electron density difference plots shown in Fig. 6, where the largest values are found on corrin carbons in the reduced methylcobalamin base-on and baseoff forms. As mentioned in the "Cobalt complexes" section, the reduced cobalamin occurs in the base-off form where the axial base is missing or replaced by a water molecule.

The results from the calculations show that for dimethylglyoxime cobalt complex with the axial pyridine ligand the $\mathrm{Co}-\mathrm{CH}_{3}$ bond energy is somewhat larger (about $3.5 \mathrm{kcal}$ ) than in methylcobalamin. After the reduction methyl binding energy decreases of about $10 \mathrm{kcal}$ (to $33 \mathrm{kcal}$, Table 2). Unlike as in cobalamins, after reduction of $\mathrm{Co}\left(\mathrm{dmgBF}_{2}\right)_{2} \mathrm{py}$, the pyridine ligand is not detached. When the pyridine ligand is missing (for $\mathbf{8}$ and 9), the methyl-cobalt binding energy for the oxidized and reduced forms are very similar (about $40 \mathrm{kcal}$ ), which is also different than in the case of MeCbl. These differences can be explained by inspecting the spin densities of the reduced cobalt complexes gathered in Table 3. The spin densities in reduced glyoximate complexes show that reduction occurs partially on the dimetyloglyoxime ligand and partially on cobalt atom, which is in contrast to cobalamins, where it occurs solely on corrin. This can be traced to more negatively charged cobaloxime than corrin ring $(-2$ vs. -1$)$. This is also visible in Fig. 6 where pronounced values of electron density differences are present on cobalt and methyl. The calculated methyl binding energy in 6 from Table 2 (42 kcal) is larger than measured for $\mathrm{CH}_{3} \mathrm{Co}(\mathrm{dmgh})_{2}$ py [52] amounting to $33.1 \mathrm{kcal}$; on the other hand, it is close to calculated value of $41.06 \mathrm{kcal}$ for $\mathrm{CH}_{3} \mathrm{Co}(\mathrm{dmgH})_{2} \mathrm{NH}_{3}$ [77] and $40.7 \mathrm{kcal}$ for $\mathrm{CH}_{3} \mathrm{Co}(\mathrm{dmgH})_{2} \mathrm{NHCH}_{2}$ [68].

For the nickel complex with the $\mathrm{PPh}_{2} \mathrm{CH}_{2} \mathrm{CH}_{2} \mathrm{SEt}$ ligand, the methyl binding energy is given only for the lowest energy conformer (MeVI in Fig. 3 and in Table S1), 


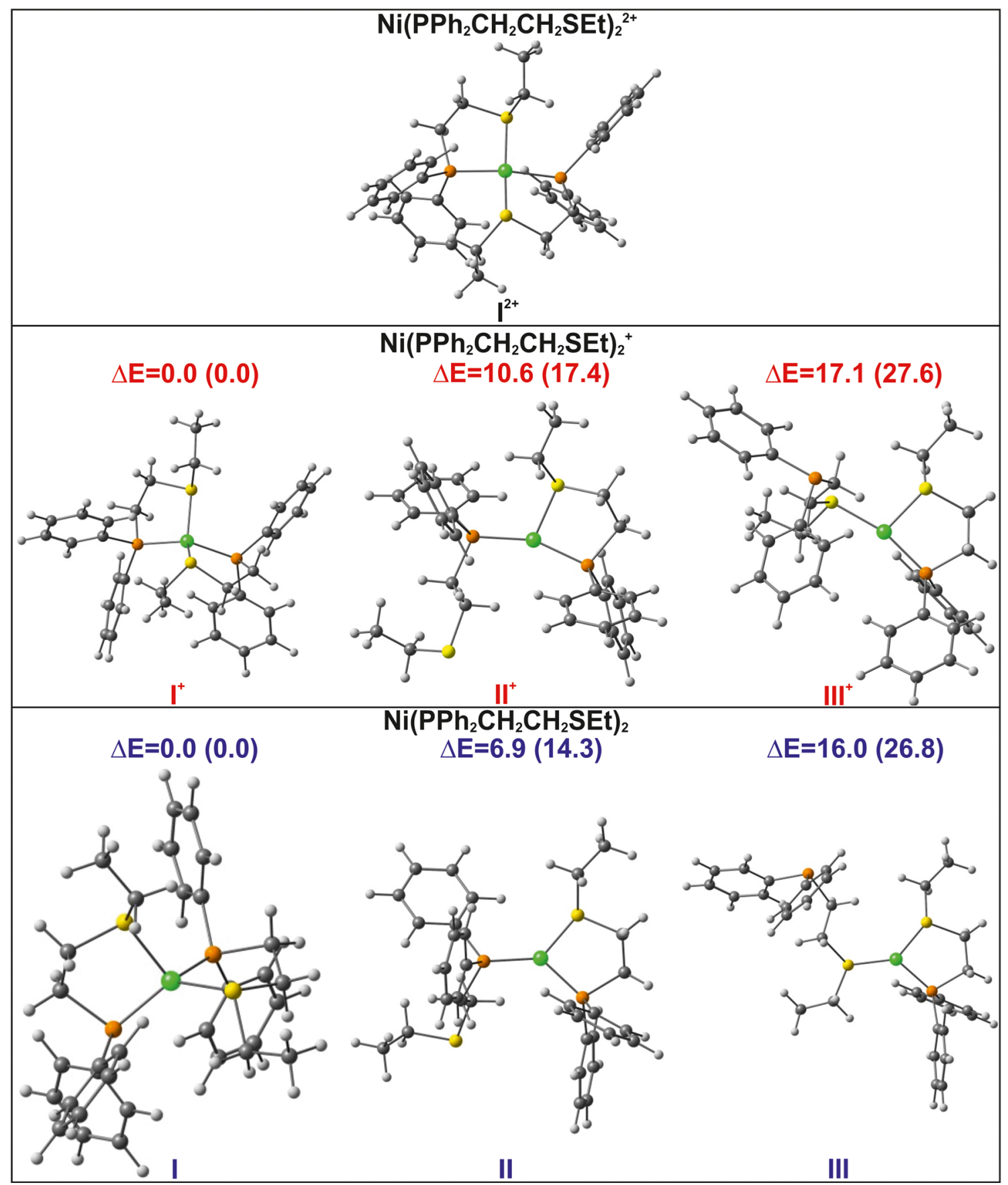

Fig. 3 The optimized structures of nickel complexes with $\mathrm{PPh}_{2} \mathrm{CH}_{2} \mathrm{CH}_{2} \mathrm{SEt}$ ligand. $\Delta E$ (in $\mathrm{kcal} / \mathrm{mol}$ ) denotes relative energy obtained from BP86 optimization, in parentheses the $\mathrm{G} 3$ correction is taken into account

and it amounts to $50.1 \mathrm{kcal} / \mathrm{mol}$. The $\mathrm{Ni}-\mathrm{CH}_{3}$ bond energy calculated for the $\mathrm{CH}_{3} \mathrm{Ni}$ (Triphos) ${ }^{+}$complex is 52.3 $\mathrm{kcal} / \mathrm{mol}$ and is the largest among all calculated $\mathrm{E}_{B}$ values. To the best of our knowledge, the nickel-methyl binding energies were not determined experimentally. For both nickel complexes, the calculated methyl binding energies are larger than those for cobalt cobaloximes and cobalamins. This accounts for the fact that the methyl is transferred from cobalt to nickel complex.
In Table 4, the NBO bonding analysis for metal-methyl bond is given for cobalt and nickel complexes. Concerning the cobalt complexes it can be seen that the bonding $\sigma_{\mathrm{Co}-\mathrm{CH}_{3}}$ orbital has approximately equal percentage participation of cobalt and carbon hybridized atomic orbitals (between $47 \%$ and 53\%). The larger deviation is for $\mathrm{CH}_{3} \mathrm{Co}\left(\mathrm{dmgBF}_{2}\right)_{2}$ with $43 \%$ and $57 \%$ cobalt and carbon orbital participation, respectively. For nickel complexes, the metal contribution to the bonding orbital amounts to $35 \%$ 


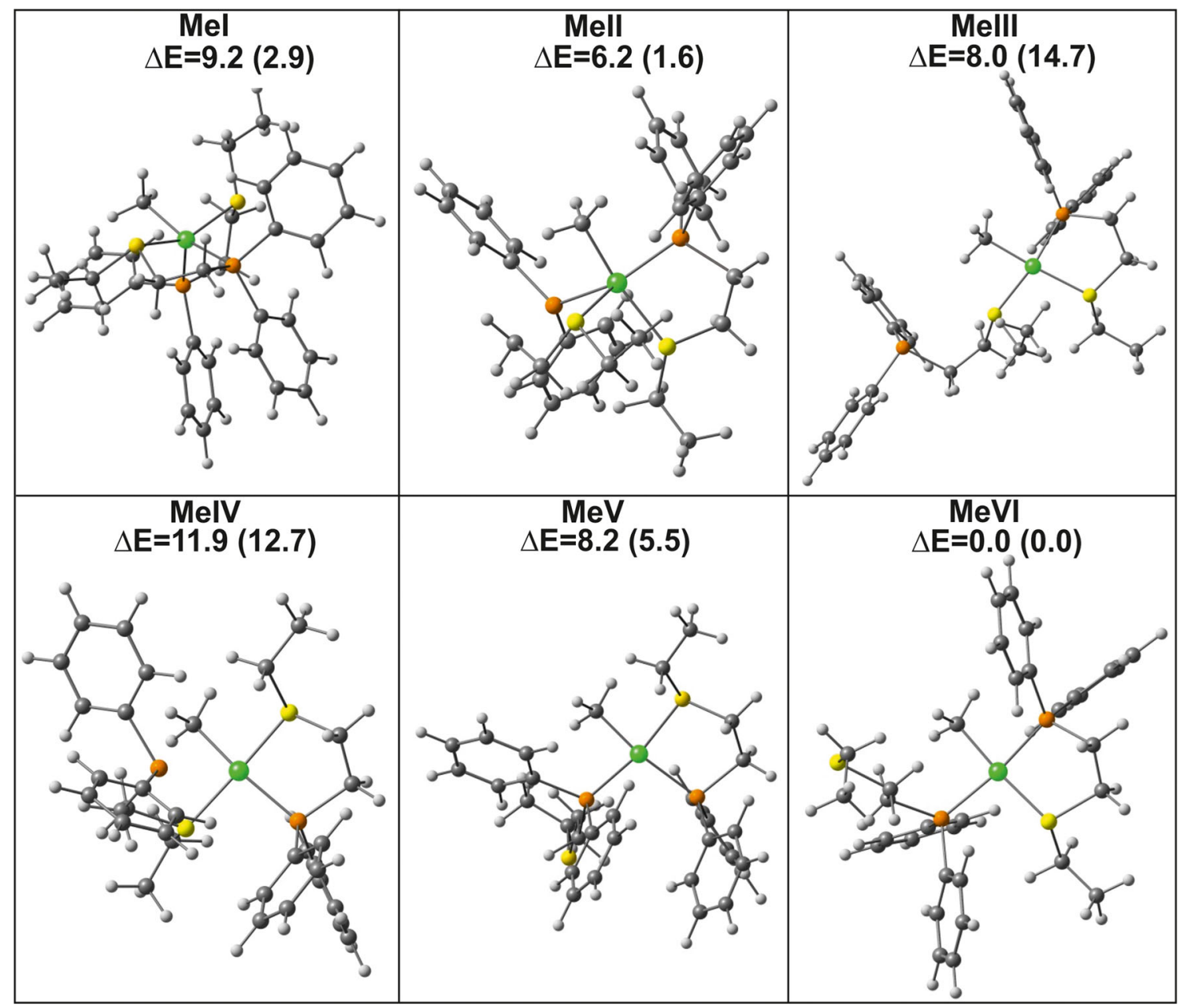

Fig. 4 The optimized structures of methyl-nickel $\mathrm{CH}_{3} \mathrm{Ni}\left(\mathrm{PPh}_{2} \mathrm{CH}_{2} \mathrm{CH}_{2} \mathrm{SEt}\right)_{2}^{+}$complex. $\Delta E$ (in kcal/mol) denotes relative energy obtained from BP86 optimization, in parentheses the $\mathrm{G} 3$ correction is taken into account

and carbon to $65 \%$. Thus, some ionic character in $\mathrm{Ni}-$ $\mathrm{CH}_{3}$ bonding can be inferred with participation of formally $\mathrm{CH}_{3}^{-}$ion. In turn, the cobalt-methyl bond can be viewed as basically covalent.

In Table S5, NBO charges are collected for methyl-nickel and methyl-cobalt complexes. For cobalt complexes, the charge on the metal and the methyl group is positive, except for the reduced base-on glyoxime complex, where the metal is negative. The charge on metal and methyl in reduced and non-reduced cobalamin complexes is practically the same, indicating that the reduction occurs predominantly on the corrin ring. On the other hand, metal and methyl group are both more negative in the cobalt glyoximate reduced complexes. This corroborates with data in Table 3 and confirms the different behaviors of glyoximate and corrinate cobalt-methyl complexes upon reduction. These differences are due to the charge of the macrocyclic ligand, minus one for corrin and minus two for glyoxime, so the corrin ligand can accept a larger charge as a result of the reduction. In turn, in the methyl nickel complexes, the methyl group and nickel have negative charges.

\section{Redox potentials}

Redox potentials were calculated according to the equation:

$E_{\text {redox }}=E\left(M^{n+1}\right)_{\text {sol }}-E\left(M^{n}\right)_{s o l}-4.34(S H E)$

The value of standard hydrogen electrode potential was taken from [78]. The obtained results are summarized in Table 5 and compared with experimental data. Because redox potentials were measured with the use of different reference electrodes, we converted all values to the standard hydrogen electrode (SHE). There were several measurements of redox potentials for various cobalamin forms [72, 75, 79-81]. The cobalamin redox potentials were also calculated theoretically [56, 64]. The calculations performed with BP86 functional show that it gives good 
Fig. 5 The structure of $\mathrm{Ni}$ (Triphos) complexes

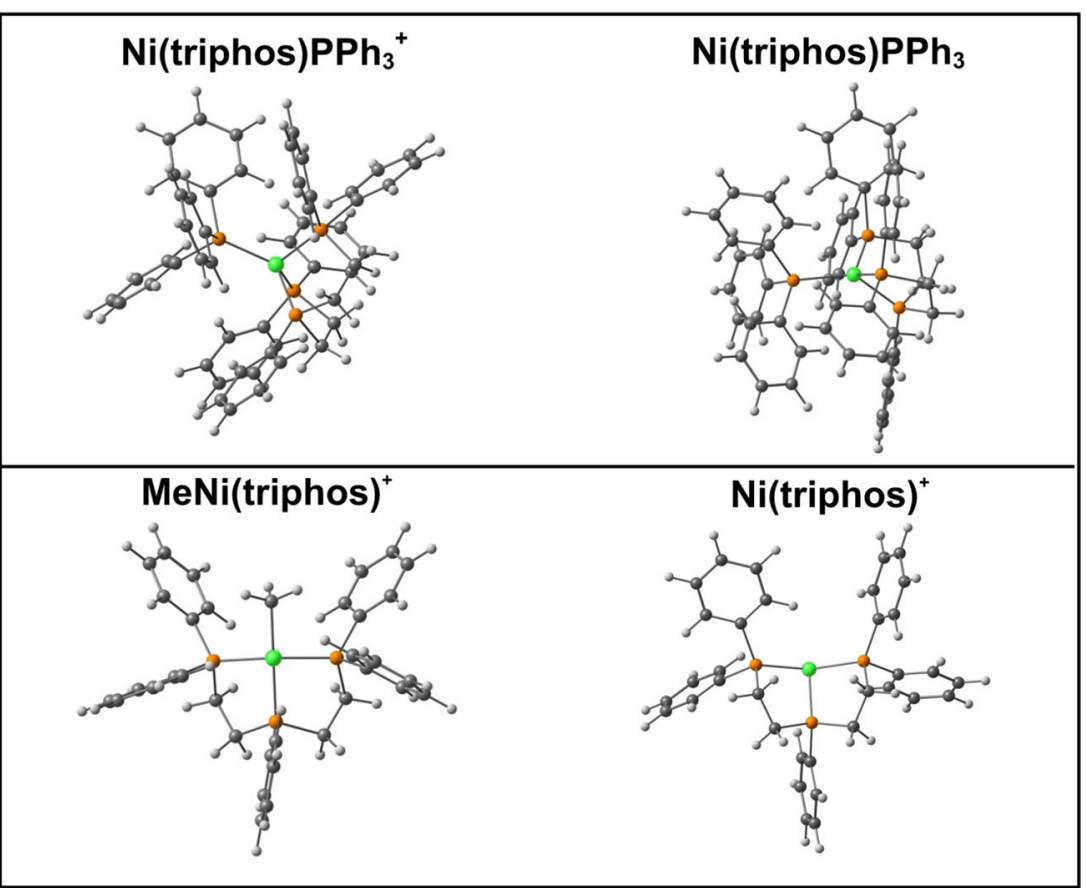

results for redox potentials of transition metal complexes [36-38].

Generally, it can be noted (Table 5) that the BP86 calculated redox potentials are in good agreement with the experimental data (maximum difference up to $0.2 \mathrm{eV}$ ). From the results it can be seen that for base-off cobalamins the redox potentials are more positive that for the base-on ones. For cobaloxime complexes, calculated values of redox potentials are significantly more positive in comparison with similar forms of cobalamin complexes.

In regard to the reactions (2) and (3), there may be $S_{N} 2$ or radical mechanisms involved, the latter one with electron transfer from the nickel complex to methylcobalamin or methyl derivative of cobalt dimethylglyoximate. Looking

Table 2 Methyl binding energy $\mathrm{E}_{B}(\mathrm{kcal} / \mathrm{mol})$

\begin{tabular}{|c|c|c|c|c|c|}
\hline & Molecule & $\Delta \mathrm{E}+\mathrm{ZPE}$ & $\begin{array}{l}\Delta \mathrm{E}+\mathrm{ZPE} \\
+\mathrm{D} 3\end{array}$ & $\begin{array}{l}\Delta \mathrm{E}+\mathrm{ZPE} \\
+\mathrm{D} 3+\mathrm{BSSE}\end{array}$ & Exp. \\
\hline 1 & $\mathrm{CH}_{3} \mathrm{CoCorIm}^{+}$ & 30.4 & 40.0 & 38.7 & $37 \pm 3^{\mathrm{a}}, 36 \pm 4^{\mathrm{b}}, 39 \pm 5^{\mathrm{c}}$ \\
\hline 2 & $\mathrm{CH}_{3} \mathrm{CoCor}^{+}$ & 34.9 & 44.4 & 43.0 & \\
\hline 3 & $\mathrm{CH}_{3} \mathrm{CoCor}$ & 13.0 & 21.7 & 20.2 & \\
\hline 4 & $\mathrm{CH}_{3} \mathrm{CoCorH}_{2} \mathrm{O}^{+}$ & 32.1 & 41.4 & 40.0 & $44.6^{\mathrm{d}}, 42 \pm 5^{\mathrm{c}}$ \\
\hline 5 & $\mathrm{CH}_{3} \mathrm{CoCorH}_{2} \mathrm{O}$ & 9.6 & 19.8 & 18.4 & $19.0^{\mathrm{e}}$ \\
\hline 6 & $\mathrm{CH}_{3} \mathrm{Co}\left(\mathrm{dmgBF}_{2}\right)_{2}$ py & 33.8 & 43.5 & 42.2 & $33.1^{\mathrm{f}}$ \\
\hline 7 & $\mathrm{CH}_{3} \mathrm{Co}\left(\mathrm{dmgBF}_{2}\right)_{2} \mathrm{py}^{-}$ & 19.0 & 34.4 & 33.0 & \\
\hline 8 & $\mathrm{CH}_{3} \mathrm{Co}\left(\mathrm{dmgBF}_{2}\right)_{2}$ & 32.5 & 41.1 & 39.7 & \\
\hline 9 & $\mathrm{CH}_{3} \mathrm{Co}\left(\mathrm{dmgBF}_{2}\right)_{2}^{-}$ & 31.5 & 39.7 & 38.1 & \\
\hline 10 & $\mathrm{CH}_{3} \mathrm{Ni}\left(\mathrm{PPh}_{2} \mathrm{CH}_{2} \mathrm{CH}_{2} \mathrm{SEt}\right)_{2}^{+\mathrm{g}}$ & 40.0 & 51.8 & 50.1 & \\
\hline 11 & $\mathrm{CH}_{3} \mathrm{Ni}$ (Triphos) $)^{+}$ & 44.5 & 54.6 & 52.9 & \\
\hline
\end{tabular}

${ }^{\mathrm{a}}$ Ref. [60]

${ }^{\mathrm{b}}$ Ref. [83]

${ }^{\mathrm{c}}$ Ref. [84]

${ }^{\mathrm{a}}$ Gas phase, Ref. [61]

${ }^{\text {e }}$ Ref. [75]

${ }^{\mathrm{f}}$ For $\mathrm{CH}_{3}(\mathrm{dmgH})_{2}$ py, Ref. [52]

gFor the lowest energy conformer MeVI (Fig. 4 and Table S1) 
Table 3 Spin densities in the reduced cobalamin and dimethylglyoxime cobalt complexes

\begin{tabular}{|c|c|c|c|}
\hline & $\mathrm{Co}$ & Cor & $\mathrm{CH}_{3}$ \\
\hline $\mathrm{CH}_{3}$ CoCorIm & -0.052 & -0.949 & 0.003 \\
\hline $\mathrm{CH}_{3} \mathrm{CoCor}$ & $-0,046$ & -0.958 & 0.004 \\
\hline \multirow[t]{2}{*}{$\mathrm{CH}_{3} \mathrm{CoCorH}_{2} \mathrm{O}$} & -0.048 & -0.944 & 0.004 \\
\hline & Co & $\left(\mathrm{dmgBF}_{2}\right)_{2}$ & $\mathrm{CH}_{3}$ \\
\hline $\mathrm{CH}_{3} \mathrm{Co}\left(\mathrm{dmgBF}_{2}\right)_{2} \mathrm{py}^{-}$ & -0.300 & -0.644 & 0.023 \\
\hline $\mathrm{CH}_{3} \mathrm{Co}\left(\mathrm{dmgBF}_{2}\right)_{2}^{-}$ & -0.333 & -0.590 & -0.077 \\
\hline
\end{tabular}

Fig. 6 Cross-sectional contours along the axial bonding for electron density difference between the oxidized and reduced form of selected cobalamin and dimethylglyoxime cobalt complexes, contour values between -0.001 a.u (blue) and 0.001 a.u. (red)

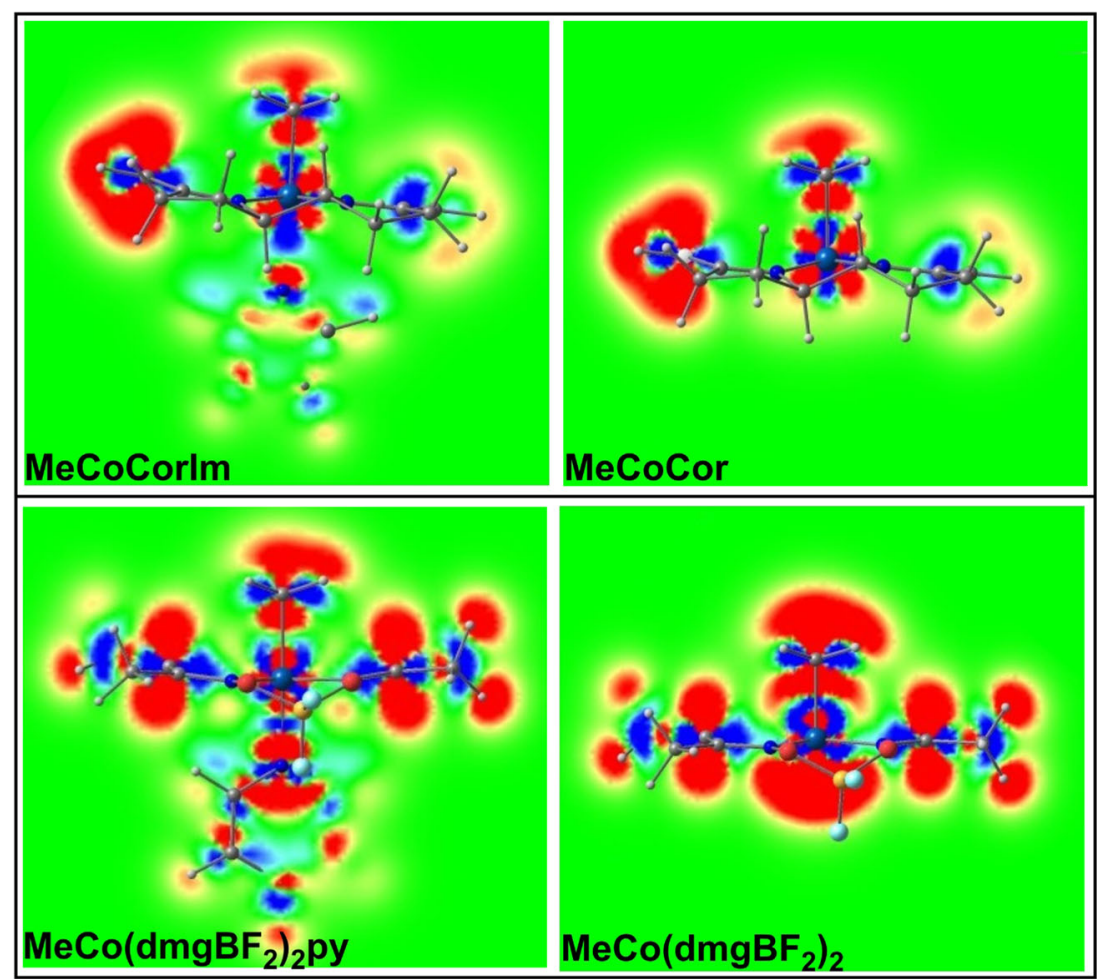

Table 4 NBO analysis of axial bonds for cobalamin and dimethylglyoxime cobalt complexes (the hybridization of the atoms is indicated with the percent contribution of the metal-centered $d$ or (and) $p$ orbitals as a superscript, LP denotes an electron lone pair)

\begin{tabular}{lll}
\hline $\mathrm{NBO}$ & Occupancy & \\
\hline $\mathrm{CH}_{3} \mathrm{CoCorIm}{ }^{+}$ & & \\
$\sigma_{\mathrm{Co}-C_{C H_{3}}}$ & 1.8093 & {$[47 \%] 0.6848\left(s p^{13.19} d^{54.29}\right)_{C o}+[53 \%] 0.7287\left(s p^{81.11}\right)_{C}$} \\
$\sigma_{\mathrm{Co}-C_{C H_{3}}}^{*}$ & 0.1326 & {$[53 \%] 0.7287\left(s p^{13.19} d^{54.29}\right)_{C o}-[47 \%] 0.6848\left(s p^{81.11}\right)_{C}$} \\
$L P\left(N_{I m}\right)$ & 1.6858 & $s p^{62.99}$ \\
$\mathrm{CH}_{3} \mathrm{CoCorH}_{2} \mathrm{O}^{+}$ & & \\
$\sigma_{\mathrm{Co}-C_{C H_{3}}}$ & 1.8167 & {$[49 \%] 0.7033\left(s p^{8.29} d^{57.87}\right)_{C o}+[51 \%] 0.7109\left(s p^{82.37}\right)_{C}$} \\
$\sigma_{\mathrm{Co}-C_{C H_{3}}^{*}}^{*}$ & 0.1161 & {$[51 \%] 0.7109\left(s p^{8.29} d^{57.87}\right)_{C o}-[49 \%] 0.7033\left(s p^{82.37}\right)_{C}$} \\
$L P\left(O_{H_{2} O}\right)$ & 1.9908 & $s p^{69.75}$ \\
$L P\left(O_{H_{2} O}\right)$ & 1.8715 & $s p^{76.39}$ \\
$\mathrm{CH}_{3} \mathrm{CoCor}^{+}$ & & {$[51 \%] 0.7176\left(s p^{4.43} d^{60.81}\right)_{C o}+[49 \%] 0.6965\left(s p^{83.72}\right)_{C}$} \\
$\sigma_{C o-C_{C H}}$ & 1.8258 & {$[49 \%] 0.6965\left(s p^{4.43} d^{60.81}\right)_{C o}-[51 \%] 0.7176\left(s p^{83.72}\right)_{C}$} \\
$\sigma_{C o-C_{C H}}^{*}$ & 0.1245 &
\end{tabular}


Table 4 (continued)

\begin{tabular}{|c|c|c|}
\hline NBO & Occupancy & \\
\hline \multicolumn{3}{|c|}{$\mathrm{CH}_{3} \mathrm{Co}\left(\mathrm{dmgBF}_{2}\right)_{2}$ py } \\
\hline$\sigma_{\mathrm{Co}-\mathrm{C}_{\mathrm{CH}}}$ & 1.6952 & {$[43 \%] 0.6594\left(s p^{45.18} d^{38.00}\right)_{C o}+[57 \%] 0.7518\left(s p^{81.67}\right)_{C}$} \\
\hline$\sigma_{C o-N_{p y}}$ & 1.8863 & {$[17 \%] 0.4147\left(s p^{54.68} d^{29.42}\right)_{C o}+[83 \%] 0.9099\left(s p^{71.82}\right)_{N}$} \\
\hline$\sigma_{\mathrm{Co}-\mathrm{C}_{\mathrm{CH}}}^{*}$ & 0.0805 & {$[57 \%] 0.7518\left(s p^{45.18} d^{38.00}\right)_{C o}-[43 \%] 0.6594\left(s p^{81.67}\right)_{C}$} \\
\hline$\sigma_{C o-N_{p y}}^{*}$ & 0.1686 & {$[83 \%] 0.9099\left(s p^{54.68} d^{29.42}\right)_{C o}-[17 \%] 0.4147\left(s p^{71.82}\right)_{N}$} \\
\hline \multicolumn{3}{|c|}{$\mathrm{CH}_{3} \mathrm{Co}\left(\mathrm{dmgBF}_{2}\right)_{2}$} \\
\hline$\sigma_{\mathrm{Co}-\mathrm{C}_{\mathrm{CH}_{3}}}$ & 1.8241 & {$[52 \%] 0.7203\left(s p^{5.13} d^{61.09}\right)_{C o}+[48 \%] 0.6936\left(s p^{84.94}\right)_{C}$} \\
\hline$\sigma_{\mathrm{Co}-\mathrm{C}_{\mathrm{CH}}}^{*}$ & 0.0691 & {$[48 \%] 0.6936\left(s p^{5.13} d^{61.09}\right)_{C o}-[52 \%] 0.7203\left(s p^{84.94}\right)_{C}$} \\
\hline \multicolumn{3}{|c|}{$\mathrm{CH}_{3} \mathrm{Ni}\left(\mathrm{PPh}_{2} \mathrm{CH}_{2} \mathrm{CH}_{2} \mathrm{SEt}\right)_{2}^{+\mathrm{a}}$} \\
\hline$\sigma_{\mathrm{Ni}-\mathrm{C}_{\mathrm{CH}}}$ & 1.7679 & {$[35 \%] 0.5907\left(s p^{42.99} d^{34.48}\right)_{N i}+[65 \%] 0.8069\left(s p^{79.18}\right)_{C}$} \\
\hline$\sigma_{N i-S_{\text {trans }}}$ & 1.9082 & {$[20 \%] 0.4481\left(s p^{56.68} d^{22.53}\right)_{N i}+[80 \%] 0.8940\left(s p^{80.19}\right)_{S}$} \\
\hline$\sigma_{\mathrm{Ni}-\mathrm{C}_{\mathrm{CH}_{3}}}^{*}$ & 0.1237 & {$[65 \%] 0.8069\left(s p^{42.99} d^{34.48}\right)_{N i}-[35 \%] 0.5907\left(s p^{79.18}\right)_{C}$} \\
\hline$\sigma_{N i-S_{\text {trans }}}^{*}$ & 0.1295 & {$[80 \%] 0.8940\left(s p^{56.68} d^{22.53}\right)_{N i}-[20 \%] 0.4481\left(s p^{80.19}\right)_{S}$} \\
\hline \multicolumn{3}{|c|}{$\mathrm{CH}_{3} \mathrm{Ni}$ (Triphos) $)^{+}$} \\
\hline$\sigma_{\mathrm{Ni}-\mathrm{C}_{\mathrm{CH}_{3}}}$ & 1.7856 & {$[35 \%] 0.5894\left(s p^{42.73} d^{33.16}\right)_{N i}+[65 \%] 0.8078\left(s p^{79.23}\right)_{C}$} \\
\hline$\sigma_{N i-P_{t r a n s}}$ & 1.8443 & {$[28 \%] 0.5258\left(s p^{57.18} d^{22.48}\right)_{N i}+[72 \%] 0.8506\left(s p^{70.42}\right)_{P}$} \\
\hline$\sigma_{\mathrm{Ni}-\mathrm{C}_{\mathrm{CH}_{3}}}^{*}$ & 0.1290 & {$[65 \%] 0.8078\left(s p^{42.73} d^{33.16}\right)_{N i}-[35 \%] 0.5894\left(s p^{79.23}\right)_{C}$} \\
\hline$\sigma_{N i-P_{\text {trans }}}^{*}$ & 0.1311 & {$[72 \%] 0.8506\left(s p^{57.18} d^{22.48}\right)_{N i}-[28 \%] 0.5258\left(s p^{70.42}\right)_{P}$} \\
\hline
\end{tabular}

${ }^{a}$ For the lowest energy conformer (MeVI, Fig. 4 and Table S1)

Table 5 Redox potentials $\mathrm{E}_{\text {redox }}(\mathrm{V})$

\begin{tabular}{|c|c|c|c|c|c|}
\hline & & Calculated & Exp. & SHE & $\Delta E_{0}^{\mathrm{a}}$ \\
\hline $\mathrm{CH}_{3} \mathrm{CoCorIm}+/ \mathrm{CH}_{3}$ CoCorIm & & -1.58 & $-1.60^{\mathrm{b}, \mathrm{f}}$ & -1.36 & $(-0.22)$ \\
\hline $\mathrm{CH}_{3} \mathrm{CoCor}^{+} / \mathrm{CH}_{3}$ CoCor & & -1.41 & $-1.45^{\mathrm{b}, \mathrm{g}}$ & -1.21 & $(-0.20)$ \\
\hline CoCorIm $^{+} /$CoCorIm & & -0.78 & $-0.85^{\mathrm{b}, \mathrm{g}}$ & -0.61 & $(-0.17)$ \\
\hline $\mathrm{CH}_{3} \mathrm{CoCorH}_{2} \mathrm{O}^{+} / \mathrm{CH}_{3} \mathrm{CoCorH}_{2} \mathrm{O}$ & & -1.40 & & & \\
\hline $\mathrm{CoCorH}_{2} \mathrm{O}^{+} / \mathrm{CoCorH}_{2} \mathrm{O}$ & & -0.36 & $-0.74^{\mathrm{b}, \mathrm{g}}$ & -0.50 & $(0.14)$ \\
\hline $\mathrm{CoCor}^{+} / \mathrm{CoCor}$ & & -0.38 & & & \\
\hline $\mathrm{CH}_{3} \mathrm{Co}\left(\mathrm{dmgBF}_{2}\right)_{2} \mathrm{py} / \mathrm{CH}_{3} \mathrm{Co}\left(\mathrm{dmgBF}_{2}\right)_{2} \mathrm{py}^{-}$ & & -0.99 & $-1.10^{\mathrm{c}, \mathrm{h}}$ & -1.10 & $(0.11)$ \\
\hline $\mathrm{CH}_{3} \mathrm{Co}\left(\mathrm{dmgBF}_{2}\right)_{2} / \mathrm{CH}_{3} \mathrm{Co}\left(\mathrm{dmgBF}_{2}\right)_{2}^{-}$ & & -0.15 & & & \\
\hline $\mathrm{Co}\left(\mathrm{dmgBF}_{2}\right)_{2} \mathrm{py} / \mathrm{Co}\left(\mathrm{dmgBF}_{2}\right)_{2} \mathrm{py}^{-}$ & & -0.14 & & & \\
\hline $\mathrm{Co}\left(\mathrm{dmgBF}_{2}\right)_{2} / \mathrm{Co}\left(\mathrm{dmgBF}_{2}\right)_{2}^{-}$ & & -0.08 & $-0.55^{\mathrm{b}, \mathrm{j}}$ & -0.31 & $(0.23)$ \\
\hline $\mathrm{Ni}\left(\mathrm{PPh}_{2} \mathrm{CH}_{2} \mathrm{CH}_{2} \mathrm{SEt}\right)_{2}^{2+} / \mathrm{Ni}\left(\mathrm{PPh}_{2} \mathrm{CH}_{2} \mathrm{CH}_{2} \mathrm{SEt}\right)_{2}^{+}$ & & 0.01 & $-0.56^{\mathrm{d}, \mathrm{i}}$ & -0.02 & $(0.03)$ \\
\hline $\mathrm{Ni}\left(\mathrm{PPh}_{2} \mathrm{CH}_{2} \mathrm{CH}_{2} \mathrm{SEt}\right)_{2}^{+} / \mathrm{Ni}\left(\mathrm{PPh}_{2} \mathrm{CH}_{2} \mathrm{CH}_{2} \mathrm{SEt}\right)_{2}$ & $\mathbf{I}^{\mathrm{e}}$ & -0.65 & $-1.14^{\mathrm{d}, \mathrm{i}}$ & -0.60 & $(-0.05)$ \\
\hline $\mathrm{Ni}\left(\right.$ Triphos) $\mathrm{PPh}_{3}^{+} / \mathrm{Ni}$ (Triphos) $\mathrm{PPh}_{3}$ & & -0.30 & $-0.10^{\mathrm{c}, \mathrm{h}}$ & -0.10 & $(-0.20)$ \\
\hline
\end{tabular}

${ }^{\mathrm{a}} \Delta E_{0}=E_{0}^{\text {calc }}-E_{0}^{S H E}$

${ }^{\mathrm{b}} \mathrm{SCE}=$ the standard calomel electrode

${ }^{\mathrm{c}} \mathrm{SHE}=$ the standard hydrogen electrode

${ }^{\mathrm{d}} \mathrm{Ag} / \mathrm{AgNO}_{3}=$ the standard silver electrode

${ }^{\mathrm{e}}$ For the lowest energy conformers (Table S1)

${ }^{\mathrm{f}}$ Ref. [72]

${ }^{g}$ Ref. [79]

${ }^{\mathrm{h}}$ Ref. [28]

${ }^{\mathrm{i}}$ Ref. [10]

${ }^{\mathrm{j}}$ Ref. [85] 
at the calculated reduction potentials of these complexes in Table 5, one can see that the reduction potentials of nickel complexes are in most cases much higher than for the base-on and base-off cobalamins and higher than for the methyl-cobalt dimethylglyoxime complexes with a pyridine ligand (baseon). This makes the radical reductive mechanism unlikely. On the other hand, the reduction potential of methyl cobalt glyoximate without pyridyne (base-off) is significantly higher than that for the base-on, contrary than in cobalamnis. Thus, the radical-reductive mechanism in principle could be possible for base-off glyoximate. This is probably not the case, because a pyridine or solvent molecule is attached to the cobalt atom in glyoximate complexes.

\section{Conclusions}

Several cobalt and nickel complexes involved in the methyl transfer reactions were examined with the DFT method using BP86 functional. The geometries, methyl binding energies and redox potentials of all the species were studied. For reduced cobalamins axial base undergo dissociation, which is consistent with experiment. In the base-off forms with water as an axial ligand, water molecule is linked by hydrogen bond to corrin nitrogen $\left(\mathrm{CH}_{3} \mathrm{CoCorH}_{2} \mathrm{O}\right)$. In methyl-free cobalamin $\left(\mathrm{CoCorH}_{2} \mathrm{O}\right)$, the water molecule forms a hydrogen bond with cobalt atom.

Experimentally the five-coordinate structure for methylated nickel complex with $\mathrm{PPh}_{2} \mathrm{CH}_{2} \mathrm{CH}_{2} \mathrm{SEt}$ ligand is suggested. Our calculations give small energy difference between five- and four-coordinate forms $(1.6 \mathrm{kcal})$ which may imply fast interconversion between them.

There are noticeable differences in geometry, $\mathrm{Co}-\mathrm{CH}_{3}$ binding energies and redox potentials between cobalamin and dimethylglyoxime complexes, which indicates that chemical properties of these two systems are different. On the basis of the experimental redox potentials $(-1.1$ for $\mathrm{CH}_{3} \mathrm{Co}\left(\mathrm{dmgBF}_{2}\right)_{2}$ py/ $\mathrm{CH}_{3} \mathrm{Co}\left(\mathrm{dmgBF}_{2}\right)_{2} \mathrm{py}^{-}$redox couple and -0.1 for $\mathrm{Ni}$ (Triphos) $\mathrm{PPh}_{3}^{+} / \mathrm{Ni}$ (Triphos) $\mathrm{PPh}_{3}$ ), it was suggested that the reaction (2) takes place according to the $\mathrm{S}_{N} 2$ mechanism [28]. In the case of radical mechanism reduction of $\mathrm{CH}_{3} \mathrm{Co}\left(\mathrm{dmgBF}_{2}\right)_{2}$ py by $\mathrm{Ni}$ (Triphos) $\mathrm{PPh}_{3}$ would be required. Our calculated redox potentials confirm such a statement, the calculated redox potential are equal to $-0.99 \mathrm{~V}$ and $-0.3 \mathrm{~V}$, respectively.

Reaction (2) is fast [28] which can be attributed to the fact that the binding energy of methyl in the $\mathrm{CH}_{3} \mathrm{Ni}$ (Triphos) ${ }^{+}$complex is about $10 \mathrm{kcal} / \mathrm{mol}$ higher than in the $\mathrm{CH}_{3} \mathrm{Co}\left(\mathrm{dmgBF}_{2}\right)_{2}$ py complex.

Acknowledgments The Gaussian16 calculations were carried out in the Wroclaw Centre for Networking and Supercomputing, WCSS, Wroclaw, Poland, http://www.wcss.wroc.pl, under calculational Grant No. 18.
Compliance with ethical standards This study complied with ethical standards

Conflict of interest The authors declare that they have no conflict of interest.

Open Access This article is distributed under the terms of the Creative Commons Attribution 4.0 International License (http:// creativecommons.org/licenses/by/4.0/), which permits unrestricted use, distribution, and reproduction in any medium, provided you give appropriate credit to the original author(s) and the source, provide a link to the Creative Commons license, and indicate if changes were made.

\section{References}

1. Matthews RG, Koutmos M, Datta S (2008) Cobalamin-dependent and cobamide-dependent methyltransferases. Curr Opin Struct Biol 18:658-666. https://doi.org/10.1016/j.sbi.2008.11.005

2. Matthews RG (2009) Cobalamin- and corrinoid- dependent enzymes. Met Ions Life Sci 6:53-114. https://doi.org/10.1039/BK 9781847559159-00053

3. Jensen KP, Ryde U (2009) Cobalamins uncovered by modern electronic structure calculations. Coord Chem Rev 253:769-778. https://doi.org/10.1016/j.ccr.2008.04.015

4. Svetlitchnaia T, Svetlitchnyi V, Meyer O, Dobbek H (2006) Structural insights into methyl transfer reactions of a corrinoid iron-sulfur protein involved in acetyl-CoA synthesis. Proc Natl Acad Sci U S A 103:14331-14336. https://doi.org/10.1073/pnas. 0601420103

5. Ragsdale S, Pierce E (2008) Acetogenesis and the WoodLjungdahl pathway of $\mathrm{CO}_{2}$ fixation. Biochim Biophys Acta 1784:1873-1898. https://doi.org/10.1016/j.bbapap.2008.08.012

6. Ragsdale S (2004) Life with carbon monoxide. Crit Rev Biochem Mol Biol 39:165-195. https://doi.org/10.1080/10409230490496 577

7. Drennan CL, Doukov TI, Ragsdale S (2004) The metalloclusters of carbon monoxide dehydrogenase/acetyl-CoA synthase: a story in pictures. J Biol Inorg Chem 9:511-515. https://doi.org/10.1007/s00775-004-0563-y

8. Lindahl PA (2004) Acetyl-coenzyme A synthase: the case for a $\mathrm{Ni}_{p}(0)$ - based mechanism of catalysis. J Biol Inorg Chem 9:516-524. https://doi.org/10.1007/s00775-004-0564-x

9. Gencic S, Grahame D (2008) Two separate one-electron steps in the reductive activation of the a cluster in subunit beta of the acds complex in methanosarcina thermophila. Biochemistry 47:5544-5555. https://doi.org/10.1021/bi7024035

10. Hsiao YM, Chojnacki SS, Hinton P, Reibenspies JH, Darensbourg MY (1993) Organometallic chemistry of sulfur/phosphorus donor ligand complexes of nickel(II) and nickel(0). Organometallics 12:870-875. https://doi.org/10.1021/om00027a041

11. Tan X, Surovtsev IV, Lindahl PA (2006) Kinetics of CO insertion and acetyl group transfer steps, and a model of the acetyl-CoA synthase catalytic mechanism. J Am Chem Soc 128:12331-12338. https://doi.org/10.1021/ja0627702

12. Seravalli J, Kumar M, Ragsdale S (2002) Rapid kinetic studies of acetyl-CoA synthesis: evidence supporting the catalytic intermediacy of a paramagnetic $\mathrm{NiFeC}$ species in the autotrophic Wood-Ljungdahl pathway. Biochemistry 41(6):1807-1819

13. Seravalli J, Ragsdale S (2008) Pulse-chase studies of the synthesis of acetyl-CoA by carbon monoxide dehydrogenase/acetyl-CoA 
synthase: evidence for a random mechanism of methyl and carbonyl addition. J Biol Chem 283:8384-8394. https://doi.org/10. 1074/jbc.M709470200

14. Ito M, Kotera M, Matsumoto T, Tatsumi K (2009) Dinuclear nickel complexes modeling the structure and function of the acetyl CoA synthase active site. Proc Natl Acad Sci U S A 106:11862-11866. https://doi.org/10.1073/pnas.0900433106

15. Rigo P, Bressan M, Basato M (1979) Nickel(0) complexes with the hybrid bidentate ligand 1-(thioethyl)-2(diphenylphosphino)ethane. Synthesis and catalytic properties of the related nickel hydride derivative. Inorg Chem 18:860-863. https://doi.org/10.1021/ic50193a064

16. Stavropoulos P, Muetterties MC, Carrie M, Holm RH (1991) Structural and reaction chemistry of nickel complexes in relation to carbon monoxide dehydrogenase: a reaction system simulating acetyl-coenzyme A synthase activity. J Am Chem Soc 113:84858492. https://doi.org/10.1021/ja00022a041

17. Kitto HJ, Rae AD, Webster RD, Willis AC, Wild SB (2007) Synthesis, structure, and electrochemistry of di- and zerovalent nickel, palladium, and platinum monomers and dimers derived from an enantiopure (S, S)-tetra(tertiary phosphine). Inorg Chem 46:8059-8070. https://doi.org/10.1021/ic700912q

18. Matsumoto T, Ito M, Kotera M, Tatsumi K A dinuclear nickel complex modeling of the nid(ii)-ni p(i) state of the active site of acetyl coa synthase, Dalton Transactions 39

19. Ram MS, Riordan CG, Yap GPA, Liable-Sands L, Rheingold AL, Marchaj A, Norton JR (1997) Kinetics and mechanism of alkyl transfer from organocobalt(III) to nickel(I): implications for the synthesis of acetyl coenzyme A by CO dehydrogenase. J Am Chem Soc 119:1648-1655. https://doi.org/10.1021/ ja963061z

20. Golden ML, Whaley CM, Rampersad MV, Reibenspies JH, Hancock RD, Darensbourg MY (2005) $\mathrm{N}_{2} \mathrm{~S}_{2} \mathrm{Ni}$ metallodithiolate complexes as ligands: structural and aqueous solutionquantitative studies of the ability of metal ions to form M-S-Ni bridges to mercapto groups coordinated to nickel(II). Implications for acetyl coenzyme A synthase. Inorg Chem 44:875-883. https://doi.org/ 10.1021/ic0489701

21. Webster CE, Darensbourg MY, Lindahl PA, Hall MB (2004) Structures and energetics of models for the active site of acetylcoenzyme A synthase: role of distal and proximal metals in catalysis. J Am Chem Soc 126:3410-3411. https://doi.org/10.1021/ ja038083h

22. Harrop TC, Olmstead MM, Mascharak PK (2006) Synthetic analogues of the active site of the A-cluster of acetyl coenzyme A synthase/CO dehydrogenase: syntheses, structures, and reactions with CO. Inorganic Cdrohemistry 45:3424-3436. https://doi.org/10.1021/ic0520465

23. Dougherty WG, Rangan K, O'Hagan MJ, Yap GP, Riordan CG (2008) Binuclear complexes containing a methylnickel moiety: relevance to organonickel intermediates in acetyl-coenzyme A synthase catalysis. J Am Chem Soc 130:13510-13511. https://doi. org/10.1021/ja803795k

24. Krishnan R, Riordan CG (2004) Cys-gly-cys tripeptide complexes of nickel: binuclear analogues for the catalytic site in acetyl coenzyme A synthase. J Am Chem Soc 126:4484-4485. https://doi.org/10.1021/ja038086u

25. Green KN, Brothers SM, Jenkins RM, Carson CE, Grapperhaus CA, Darensbourg MY (2007) An experimental and computational study of sulfur-modified nucleophilicity in a dianionic $\mathrm{NiN}_{2} \mathrm{~S}_{2}$ complex. Inorg Chem 46:7536-7544. https://doi.org/10.1021/ ic700878y

26. Schenker R, Mock MT, Kieber-Emmons MT, Riordan CG, Brunold TC (2005) Spectroscopic and computational studies on [Ni(tmc) $\left.\mathrm{CH}_{3}\right] \mathrm{OTf}$ : implications for $\mathrm{Ni}-$ methyl bonding in the
A cluster of acetyl-CoA synthase. Inorg Chem 14:3605-3617. https://doi.org/10.1021/ic0483996

27. Schenker R, Kieber-Emmons MT, Riordan CG, Brunold TC (2005) Spectroscopic and computational studies on the trans-Mu1,2-peroxo-bridged dinickel(II) species $\left[\mathrm{Ni}(\mathrm{tmc})_{2}\left(\mathrm{O}_{2}\right)\right](\mathrm{OTf})_{2}$ : nature of end-on peroxo-nickel(II) bonding and comparison with peroxo-copper(II) bonding. Inorg Chem 44:1752-1762

28. Eckert NA, Dougherty WG, Yap GPA, Riordan CG (2007) Methyl transfer from methylcobaloxime to (Triphos) Ni( $\left.\mathrm{PPh}_{3}\right)$ : relevance to the mechanism of acetyl-coenzyme A synthase. J Am Chem Soc 129:9286-9287. https://doi.org/10.1021/ja072063o

29. Kozlowski PM, Kamachi T, Kumar M, Yoshizawa K (2012) Initial step of $\mathrm{B}_{12}$-dependent enzymatic catalysis: energetic implications regarding involvement of the one-electron-reduced form of adenosylcobalamin cofactor. J Biol Inorg Chem 17:293300. https://doi.org/10.1007/s0077501108503

30. Zhou D-L, Walder P, Scheffold R, Walder L (1992) $\mathrm{S}_{N} 2$ or electron transfer? A new technique discriminates the mechanisms of oxidative addition of alkyl halides to corrinatoand porphyrinatocobalt(I). Helvetica Chimica Acta 75:995-1011. https://doi.org/10.1002/hlca.19920750403

31. Banerjee S, Ragsdale S (2003) The many faces of vitamin B12: catalysis by cobalamin-dependent enzymes. Ann Rev Biochem 72:209-247. https://doi.org/10.1146/annurev.biochem.72.121801. 161828

32. Jensen KP, Ryde U (2003) Theoretical prediction of the Co-C bond strength in cobalamins. J Phys Chem A 107:7539-7545. https://doi.org/10.1021/jp027566p

33. Dölker N, Maseras F, Lledös A (2001) A density functional study on the effect of the trans axial ligand of cobalamin on the homolytic cleavage of the $\mathrm{Co}-\mathrm{C}$ bond. J Phys Chem B 105:7564-7571. https://doi.org/10.1021/jp010144f

34. Andruniow T, Zgierski MZ, Kozlowski PM (2001) Theoretical determination of the Co-C bond energy dissociation in cobalamins. J Am Chem Soc 123:2679-2680. https://doi.org/10.1021/ ja0041728

35. Jensen KP, Ryde U (2002) The axial N-base has minor influence on Co-C bond cleavage in cobalamins. J Mol Struct 585:239-255. https://doi.org/10.1016/S0166-1280(02)00049-0

36. Emelyanova N, Sanina AF, Shestakov DFT (2013) calculations of the redox potentials for the nitrosyl complexes $\left[\mathrm{Fe}_{2}(1-\right.$ RS $)_{2}(\mathrm{NO})_{4}$ ] with R 5 alkyl. Int J Quantum Chem 113:740-744. https://doi.org/10.1002/qua.24063

37. Emelyanova N, Sanina N, Krivenko A, Manzhos R, Bozhenko K, Aldoshin S (2013) Comparison of pure and hybrid DFT functionals for geometry optimization and calculation of redox potentials for iron nitrosyl complexes with 1-SCN bridging ligands. Theor Chem Accounts 132:1316-1318. https://doi.org/10.1007/s002140 1213166

38. Castro L, Bühl M (2014) Calculations of one-electron redox potentials of oxoiron(IV) porphyrin complexes. J Chem Theory Comput 10:243-251. https://doi.org/10.1021/ct400975w

39. Gaussian 16, Revision B.01, Frisch MJ, Trucks GW, Schlegel HB, Scuseria GE, Robb MA, Cheeseman JR, Scalmani G, Barone V, Petersson GA, Nakatsuji H, Li X, Caricato M, Marenich AV, Bloino J, Janesko BG, Gomperts R, Mennucci B, Hratchian HP, Ortiz JV, Izmaylov AF, Sonnenberg JL, Williams-Young D, Ding F, Lipparini F, Egidi F, Goings J, Peng B, Petrone A, Henderson T, Ranasinghe D, Zakrzewski VG, Gao J, Rega N, Zheng G, Liang W, Hada M, Ehara M, Toyota K, Fukuda R, Hasegawa J, Ishida M, Nakajima T, Honda Y, Kitao O, Nakai H, Vreven T, Throssell K, Montgomery JA Jr, Peralta JE, Ogliaro F, Bearpark MJ, Heyd JJ, Brothers EN, Kudin KN, Staroverov VN, Keith TA, Kobayashi R, Normand J, Raghavachari K, Rendell AP, Burant JC, Iyengar SS, Tomasi J, Cossi M, Millam JM, Klene M, Adamo C, Cammi 
R, Ochterski JW, Martin RL, Morokuma K, Farkas O, Foresman JB, Fox DJ Gaussian, Inc., Wallingford CT, 2016

40. Becke AD (1988) Density-functional exchange-energy approximation with correct asymptotic behavior. Phys Rev A 38:30983100. https://doi.org/10.1103/PhysRevA.38.3098

41. Perdew JP (1986) Density-functional approximation for the correlation energy of the inhomogeneous electron gas. Phys Rev B 33(12):8822-8824. https://doi.org/10.1103/PhysRevB.33. 8822

42. Schäfer A, Huber C, Ahlrichs R (1994) Fully optimized contracted Gaussian basis sets of triple zeta valence quality for atoms $\mathrm{Li}$ to Kr. J Chem Phys 100:5829-5835. https://doi.org/10.1063/1.467 146

43. Cossi M, Rega N, Scalmani G, Barone V (2003) Energies, structures, and electronic properties of molecules in solution with the C-PCM solvation model. J Comput Chem 24:669-681. https://doi.org/10.1002/jcc.10189

44. Tomasi J, Mennucci B, Cammi R (2005) Quantum mechanical continuum solvation models. Chem Rev 105:2999-3073. https://doi.org/10.1021/cr9904009

45. Himo F, Noodleman L, Blomberg MRA, Siegbahn PEM (2002) Relative acidities of ortho-substituted phenols, as models for modified tyrosines in proteins. J Phys Chem A 106:8757-8761. https://doi.org/10.1021/jp025646n

46. Grimme S, Ehrlich S, Goerigk L (2011) Effect of the damping function in dispersion corrected density functional theory. $\mathrm{J}$ Comput Chem 32:1456-1465. https://doi.org/10.1002/jcc.21759

47. Grimme S, Antony J, Ehrlich S, Krieg H A consistent and accurate $\mathrm{ab}$ initio parametrization of density functional dispersion correction (DFT-D) for the 94 elements H-Pu. J. Chem. Phys. 132. https://doi.org/10.1063/1.3382344

48. Stich TA, Brooks AJ, Buan NR, Brunold TC (2003) Spectroscopic and computational studies of $\mathrm{Co}^{3+}$-corrinoids: spectral and electronic properties of the B12 cofactors and biologically relevant precursors. J Am Chem Soc 125:5897-5914. https://doi.org/10.1021/ja029328d

49. Jensen KP, Ryde U (2002) The axial N-Base is not important for Co-C bond cleavage in cobalamins. J Mol Struct (THEOCHEM) 585:239-255. https://doi.org/10.1016/S01661280(02)000490

50. Dölker N, Morreale A, Maseras F (2005) Computational study on the difference between the $\mathrm{Co}-\mathrm{C}$ bond dissociation energy in methylcobalamin and adenosylcobalamin. J Biol Inorg Chem 10:509-517. https://doi.org/10.1007/s00775-005-0662-4

51. Hirao H (2011) Which DFT functional performs well in the calculation of methylcobalamin? Comparison of the B3LYP and BP86 functionals and evaluation of the impact of empirical dispersion correction. J Phys Chem A 115:9308-9313. https://doi.org/10.1021/jp2052807

52. Toscano PJ, Seligson AL, Curran MT, Scrobutt AT, Sonnerberger PC (1989) Cobalt-carbon bond disruption enthalpies: the first reliable measurement of a co-methyl bde via solution thermochemical methods. Inorg Chem 28:166. https://doi.org/10.1021/ic00300a038

53. Dölker N, Maseras F, Lledós A (2001) A density functional study on the effect of the trans axial ligand of cobalamin on the homolytic cleavage of the Co-C bond. J Phys Chem B 105:75647571. https://doi.org/10.1021/jp010144f

54. Rutkowska Zbik D, Jaworska M, Witko M (2004) Application of the DFT theory to study cobalamin complexes. Struct Chem 15:431-435. https://doi.org/10.1023/B:STUC.0000037900. 67595.9f

55. Kozlowski PM, Zgierski MZ (2004) Electronic and steric influence of trans axial base on the stereoelectronic properties of cobalamins. J Phys Chem B 108:14163-14170. https://doi.org/10.1021/ jp040373c
56. Kumar N, Kuta J, Galezowski W, Kozlowski PM (2013) Electronic structure of on e-electron-oxidized form of the Methylcobalamin cofactor: Spin density distribution and Pseudo-Jahn-Teller effect. Inorg Chem 52:1762-1771. https://doi.org/10.1021/ic3013443

57. Kozlowski PM, Kumar M, Piecuch P, Li W, Bauman NP, Hansen JA, Lodowski P, Jaworska M (2012) The Cobalt-Methyl bond dissociation in Methylcobalamin: New benchmark analysis based on density functional theory and completely renormalized coupled-cluster calculations. J Chem Theory Comput 8:18701894. https://doi.org/10.1021/ct300170y

58. Hirao H, Kozlowski PM, Manoj K (2012) $\mathrm{Co}^{+}$. H interaction inspired alternate coordination geometries of biologically important cob(I)alamin: possible structural and mechanistic consequences for methyltransferases. J Biol Inorg Chem 17:1107-1121. https://doi.org/10.1007/s00775-012-0924-x

59. Muckerman JT, Fujita E (2011) Theoretical studies of the mechanism of catalytic hydrogen production by a cobaloxime. Chem Commun 47:12456-12458. https://doi.org/10.1039/c1cc15330g

60. Martin BD, Finke RG (1992) Methylcobalamin's full- vs. Half-Strength cobalt-carbon sigma bonds and bond dissociation enthalpies: $\mathrm{Co}-\mathrm{CH}_{3}$ homolysis rate Enhancement following oneantibonding-electron reduction of methlycobalamin. J Am Chem Soc 114:585-592. https://doi.org/10.1021/ja00028a027

61. Kobylianskii IJ, Widner FJ, Kräutler K, Chen P (2013) Co-C bond energies in adenosylcobinamide and methylcobinamide in the gas phase and in silico. J Am Chem Soc 135:13648-13651. https://doi.org/10.1021/ja406676p

62. Liptak MD, Brunold TC (2006) Spectroscopic and computational studies of $\mathrm{Co}^{1+}$ cobalamin: spectral and electronic properties of the superreduced $B_{12}$ cofactor. J Am Chem Soc 128:9144-9156. https://doi.org/10.1021/ja061433q

63. Liptak MD, Datta S, Matthews RG, Brunold TC (2008) Spectroscopic study of the cobalamin-dependent methionine synthase in the activation conformation: effects of the Y1139 residue and S-adenosylmethionine on the $\mathrm{B}_{12}$ cofactor. $\mathrm{J}$ Am Chem Soc 130:16374-16381. https://doi.org/10.1021/ja8038129

64. Kumar M, Kozlowski PM (2011) A biologically relevant $\mathrm{Co}^{1+\cdots} \mathrm{H}$ bond: possible implications in the protein-induced redox tuning of $\mathrm{Co}^{2+} / \mathrm{Co}^{1+}$ reduction. Angew Chem 50:8702-8705. https://doi.org/10.1002/anie.201100469

65. Andruniow T, Zgierski MZ, Kozlowski PM (2000) Density functional theory analysis of stereoelectronic properties of cobalamins. J Phys Chem B 104:10921-10927. https://doi.org/10.1021/jp000 $810 \mathrm{x}$

66. Galezowski W, Kuta J, Kozlowski PM (2008) DFT Study of $\mathrm{Co}-\mathrm{C}$ bond cleavage in the neutral and one-electron-reduced alkyl-cobalt(III) phthalocyanines. J Phys Chem B 112:3177-3183. https://doi.org/10.1021/jp0769678

67. Kuta J, Wuerges J, Randaccio L, Kozlowski PM (2009) Axial bonding in alkylcobalamins: DFT analysis of the inverse versus normal trans influence. J Phys Chem A 113:11604-11612. https://doi.org/10.1021/jp901397p

68. Bühl M, Vinković Vrĉek I, Kabrede H (2007) Dehalogenation of chloroalkenes at cobalt centers. A model density functional study. Inorg Chem 26:1494-1504. https://doi.org/10.1021/om070027s

69. Halpern J (1985) Mechanisms of coenzyme $\mathrm{B}_{12}$-dependent rearrangements. Science 227:869-875

70. Govender PP, Navizet I, Perry CB, Marques HM (2012) The cis influence of the corrin in vitamin $\mathrm{B}_{12}$ models. Chem Phys Lett 550:150-155. https://doi.org/10.1016/j.cplett.2012.08.061

71. Petrio M, Biarnés X, Kumar M, Rovira C, Kozlowski PM (2010) Reductive cleavage mechanism of $\mathrm{Co}-\mathrm{C}$ bond in cobalamindependent methionine synthase. J Phys Chem B 114:1296512971. https://doi.org/10.1021/jp1043738 
72. Birke RL, Huang Q, Spataru T, Gosser DKJ (2006) Electroreduction of a series of alkylcobalamins: mechanism of stepwise reductive cleavage of the Co-C bond. J Am Chem Soc 128:1922-1936. https://doi.org/10.1021/ja054479c

73. Kepp K (2014) Co-C dissociation of adenosylcobalamin (Coenzyme $\mathrm{B}_{12}$ ): Role of dispersion, induction effects, solvent polarity, and relativistic and thermal corrections. J Phys Chem A 118(34):7104-7117. https://doi.org/10.1021/jp503607k

74. Qu Z-W, Hansen A, Grimme S (2015) Co-C bond dissociation energies in cobalamin derivatives and dispersion effects: Anomaly or just challenging? J Chem Theory Comput 11:1037-1045. https://doi.org/10.1021/acs.jctc.5b00007

75. Lexa D, Saveant JM (1976) Electrochemistry of vitamin $B_{12}$. Role of the base-on/base-off reaction in the oxidoreduction mechanism of the $\mathrm{B}_{12 r}-\mathrm{B}_{12 s}$ system. J Am Chem Soc 98:26522658. https://doi.org/10.1021/ja00425a039

76. Kozlowski PM, Kuta J, Galezowski W (2007) Reductive cleavage mechanism of methylcobalamin: elementary steps of Co-C bond breaking. J Phys Chem B 111:7638-7645. https://doi.org/10.1021/ jp066972w

77. Govender PP, Navizet I, Perry CB, Marques HM (2013) DFT Studies of trans and cis influences in the homolysis of the $\mathrm{Co}-\mathrm{C}$ bond in models of the alkylcobalamins. J Phys Chem A 117:30573068. https://doi.org/10.1021/jp311788t

78. Han WG, Noodleman L (2011) DFT Calculations for intermediate and active states of the Diiron center with a tryptophan or tyrosine radical in Escherichia coli ribonucleotide reductase. Inorg Chem 50:2302-2320. https://doi.org/10.1021/ic1020127

79. Lexa D, Saveant JM (1983) The electrochemistry of vitamin $B_{12}$. Acc Chem Res 16:235-243. https://doi.org/10.1021/ar00091a001
80. De Tacconi NR, Lexa D, Saveant JM (1979) Electrochemistry of vitamin B-12. Kinetics and mechanisms in $\mathrm{B}_{12 a}-\mathrm{B}_{12 r}$ oxido-reduction. J Am Chem Soc 101:467-472. https://doi.org/10. 1021/ja00496a034

81. Lexa D, Saveant JM (1978) Electrochemistry of vitamin $B_{12}$. 3 . One-electron intermediates in the reduction of methylcobalamin and methylcobinamide. J Am Chem Soc 100:3220-3222. https://doi.org/10.1021/ja00478a048

82. Fasching M, Schmidt W, Kräutler B, Stupperich E, Schmidt A, Kratky C (2000) $\operatorname{Co}(\alpha-(1 \mathrm{H}-$ Imidazolyl $)-$ Co-methylcob(III)amide: model for protein-bound corrinoid cofactors. Helvetica Chimica Acta 83:2295-2316. https://doi.org/ $10.1002 / 1522-2675(20000906) 83$

83. Hung R, Grabowski J (1999) Listening to reactive intermediates: Application of photoacoustic calorimetry to vitamin $B_{12}$ compounds. J Am Chem Soc 121(6):1359-1364. https://doi.org/10.1021/ja9829620

84. Luo L, Li G, Chen H, Fu S, Zhang S (1998) Laser-induced photoacoustic calorimetric determination of enthalpy and volume changes in photolysis of 5'-deoxyadenosylcobalamin and methylcobalamin. Dalton Trans, pp 2103-2108. https://doi.org/10.1039/ A708644J

85. Hu X, Brunschwig BS, Peters JC (2007) Electrocatalytic hydrogen evolution at low overpotentials by cobalt macrocyclic glyoxime and tetraimine complexes. J Am Chem Soc 129:8988-8998. https://doi.org/10.1021/ja067876b

Publisher's note Springer Nature remains neutral with regard to jurisdictional claims in published maps and institutional affiliations. 